\title{
The Footprint and sustainability of Private Higher Education Institutions in South Africa
}

\author{
${ }^{*}$ Alan Bird ${ }^{1}$, Virimai Mugobo ${ }^{2}$ \\ ${ }^{1,2}$ Cape Peninsula University of Technology, CPUT Bellville Campus \\ Technology way Food Science \& Technology Building, Bellville South \\ Industrial, Cape Town, 7530, South Africa \\ *11255@iieconnect.co.za
}

\begin{abstract}
The current Private Higher Education Institution (PHEI) landscape in South Africa is developing rapidly, with over ninety private tertiary institutions registered with the Council for Higher Education (CHE). However, stakeholder perceptions of these PHEIs are generally negative, primarily due to the negative perceptions of the qualification obtained from the private institutions by both parents and students and questions around the sustainability of the institutions in the long run. Media reports, lack of Department of Education (DHET) support and funding, and minimum, if any, marketing and advertising from the PHEI are factors cited for these firmly entrenched perceptions from the general public. Both emerging and international markets drove the article, countries such as Singapore, Malaysia, India and Brazil; not as a comparative study, but more as a literature review on how tertiary education is managed in the private sector in these countries. In addition, developing countries and emerging markets needed to be considered in light of their experience in sustaining private education entities. The subsequent investigation of these markets proved invaluable in terms of providing similarities and, in some instances, huge differences, which contributed to establishing the critical drivers for sustaining PHEIs in South Africa. Knowing which dimensions the branding of a PHEI should focus on nullifying the negative perceptions associated with a PHEI is paramount.
\end{abstract}

Keywords: Higher Education, Sustainability of PHEIs, Negative Perceptions, Dimensions of Branding.

\section{Introduction}

Demand for tertiary education in South Africa has led to new markets and more and more local private education institutions being established. The concept of PHEIs and the branding of these institutions play a critical role in accepting PHEI qualifications by students, parents, sponsors and industry in a volatile and dynamic changing education field in South Africa (Badenhorst, 2019). 
Even though PHEIs can trace their existence back to the post-war industrial boom of the 1950s and 1960s, worldwide, as well as in South Africa (Council on Higher Education, 2020), it was only during the late 1980s and early 1990s that PHEIs began to grow and develop in South Africa. With the new dispensation led by an African National Congress (ANC) government taking over in 1994, the new government established the National Commission on Higher Education (Sehoole, 2001: 21). In addition, the adoption of the National Qualifications Framework (NQF) in 1995 saw the establishment and growth of PHEIs throughout South Africa (Fehnel, 2006).

Most of the larger PHEIs have used marketing opportunities to try and assure their future and sustainability, focusing more on the needs of the 21st century Higher Education (HE) students in South Africa. Smaller PHEIs have limited budgets and thus gain far fewer marketing opportunities. These smaller PHEIS (those with less than 250 students) have no marketing or branding models and rely more on word-of-mouth advertising. The accreditation of these smaller PHEIs is based on their ability to develop a curriculum course that is then licensed and accredited by the Department of Higher Education (Council on Higher Education, 2020). Thus, the private higher education landscape in South Africa consists of more extensive, sustainable colleges and more minor (in numbers) colleges in a highly competitive market (Syarifudin \& Ikhwan, 2020).

Froneman maintains that the changing education landscape for public universities, also known as traditional universities in South Africa, has vastly impacted the rise of PHEIs (Froneman, 2012). This has been partly due to the number of school leavers in South Africa seeking entrance to higher education significantly increasing year on year. Froneman postulates that higher education in South Africa is experiencing an unrelenting pressure to extend study opportunities to these school leavers (Froneman, 2012). This will ultimately result in increased applications and overcrowding at public universities in South Africa (Mabelebele, 2015), allowing PHEIs to find their niche in the complex field of higher education.

21st century higher education innovations such as blended learning approaches and technology-based higher education have become branding drivers (Mufron, Ikhwan, Syuhada, \& Ridlowi, 2021). They promote the modern-day student's experience and allow an educational institution to give students more individual attention because of smaller enrollment. In addition, academic freedom of 
thought amongst students in a smaller learning environment is becoming more evident (Christensen \& Eyring, 2011).

\section{Method}

The purpose of this research article will be to assess the current state of PHEIs in South Africa, highlighting both strengths and weaknesses and discussing the sustainability of these institutions in very competitive markets. The focus will be on current negative perceptions and how they can be nullified using creative marketing drivers to promote the colleges (Ikhwan, 2021).

The research methodology adopted for this article is survey data from 14 participants, used to describe and explain the status of the phenomena and collect information about their perceptions of PHEIs. This article will focus on the current state of PHEIs in South Africa and the second part on how and what these education institutions can do to remain sustainable and play a role in the higher education landscape.

\section{Result and Discussion}

\section{Current state of PHEIs}

Despite the growing boom of private higher education in South Africa, most more prominent private institutions rely on their corporate image and website branding to remain successful and profitable. Branding and brand building amongst most of the PHEIs in South Africa has relied on the 'names' of these PHEIs in the marketplace and their ability to adhere to quality standards and quality qualifications that both students and workplaces (industry) demand (MacGregor, 2008).

The 90 PHEIs in South Africa today have over 120000 full-time registered students (Council on Higher Education, 2020), and produce a wide variety of qualifications, need to adhere to community and industry standards and expectations. Badenhorst notes that a 3rd of all higher education enrolments are private institutions (Badenhorst, 2019). Froneman states that PHEIs provide skills needed for the 21st-century economy (Froneman, 2012). He argues further that market forces significantly influence private higher education. However, despite this phenomenal growth of PHEIs in South Africa, the limited marketing of the institutions could potentially derail their sustainability objectives. Branding amongst PHEIs in South Africa has 
relied mainly on their 'name' in the marketplace with limited media advertising. This points out a lack of coherence and a unified branding framework.

Traditional media and advertising have provided limited exposure of private education providers to the general public. Thus, the common ground for all PHEIs is that these institutions need to market themselves profusely (Olonisakin, 2013).

The Higher Education Act 1997 (Act 101 of 1997) facilitated the establishment of PHEIs and brought control and legislation to the growing and developing private tertiary education market. The act makes specific reference to the power and registration of PHEIs with the following provisos (Council on Higher Education, 2020):

1. Private institutions must offer quality education;

2. The public must be protected against unscrupulous and exploitative operators;

3. Students must obtain qualifications that are aligned with the Higher Education Qualifications Framework (HEQF), and registered with the National Qualifications Framework (NQF);

4. The education system should meet the goals of transforming South Africa in accordance with government policy and legislation; and

5. Private institutions must comply with the Higher Education Act (Act 101 of 1997) (mentioned above).

In addition to the challenges currently facing most private higher institutions, such as negative image, absence of adequate funding, and overcrowding of students, these institutions must always comply with the conditions in the legislation governing their operations. Thus, PHEIs need to find their niche in the complex field of higher education (Ramdass \& Kruger, 2010).

To execute a reasonable assessment of the current standing of PHEIs in South Africa, various stakeholders with interest in PHEIs were interviewed for this research article between June 2018 and May 2020. The stakeholders comprised of students (currently studying at a PHEI), parents (invariably the ones who settle the tuition fees), sponsors (who sponsor student's fees privately or from a corporate) and corporate human resources (HR) practitioners (who employ graduates from PHEIs). The stakeholders were interviewed on aspects such as their awareness of different PHEIs; whether they were aware of the performance of these PHEIs (academic success being one of the 
indicators), the benefits/ strengths of PHEIs, and from a corporate placement perspective, whether they produced employable graduates.

Table 1, below, highlights the percentages of stakeholders relative to the dimensions given about the perceptions of PHEIs in South Africa.

Table 1. South African stakeholder perception of PHEIs

\begin{tabular}{lcccc}
\hline \multicolumn{1}{c}{$\begin{array}{c}\text { PHEIs } \\
\text { stakeholders }\end{array}$} & $\begin{array}{c}\text { Awareness } \\
\text { of different } \\
\text { PHEIs }\end{array}$ & $\begin{array}{c}\text { Performance } \\
\text { of PHEIs }\end{array}$ & $\begin{array}{c}\text { Attributes } \\
\text { of PHEIs }\end{array}$ & $\begin{array}{c}\text { Sustainability } \\
\text { of PHEIs } \\
\text { (brand equity) }\end{array}$ \\
\hline Students & $82 \%$ & $88 \%$ & $76 \%$ & $54 \%$ \\
\hline $\begin{array}{l}\text { Parents } \\
\text { (account } \\
\text { payers) }\end{array}$ & $53 \%$ & $86 \%$ & $45 \%$ & $88 \%$ \\
\hline $\begin{array}{l}\text { Sponsors } \\
\text { Corporate }\end{array}$ & $30 \%$ & $30 \%$ & $30 \%$ & $30 \%$ \\
$\begin{array}{l}\text { HR } \\
\text { practitioners }\end{array}$ & $45 \%$ & $40 \%$ & $38 \%$ & $38 \%$ \\
\hline Source: Authors own sources (taken from research study) & \\
\hline
\end{tabular}

Table 1 above indicates four different groups of stakeholders and their perceptions of PHEIs. The first group was comprised of students who were registered with a private college and studying either a Batchelor of Commerce (BCom), Batcher of Arts (BA) or Batchelor of Laws (LLB) degree. Fourteen students were interviewed, of which the majority (82\%) showed high perceptual awareness of the various PHEIs in the country. This would be attributed to contacting a marketing representative of a private college during their final school years or social media posts that they came across. The data further indicates that most students are acutely aware of the institutions they would like to study and would have an overriding say in choosing the higher education institution to enrol in.

Parents, who are invariable, the account payers show a moderate awareness (53\%) of the different PHEIs, mainly concerned with the concept of private vs public tertiary institutions rather than anyone specific PHEI. Traditionalism and the alma mater concept of which it is invariably the university the father attended, play a role in parents' awareness or lack of understanding of different types of PHEIs.

Sponsors, albeit private or corporate, finance the fees for some of the students' study fees and show a low (30\%) response rate to their understanding of different PHEIs. This could be attributed to 
sponsors being more interested in a study direction than any specific higher education institution. For example, if a Law firm is sponsoring an intern, they would finance a Batchelor of Laws degree (LLB) and leave the choice of the university to the student.

Corporate HR practitioners have a perceptual awareness of different types of PHEIs only from the perspective of employing graduates from these higher education institutions. Thus, the moderate to low (45\%) awareness of different PHEIs is attributed to corporate HR practitioners being more focused on the National Qualifications Framework (NQF) that aligns a qualification with a particular level than anyone PHEI. For example, a four year Batchelor of Laws (LLB) degree will align with NQF level 8, irrespective of which institution the student obtained their qualification- as long as the higher education institution is accredited and registered with the Department of Education (DHET).

Of the students interviewed, the performance of the PHEIs showed a high response of $88 \%$ to any performance indicators asked. Invariably, the performance indicators centred on academic success and percentage pass rates. The majority of PHEIs, in South Africa use these indicators as part of their marketing toolkit and advertise in both traditional and on social media, high pass rates- thus, students were made aware of these indicators. From a student perspective, these performance indicators are part of what is expected from a PHEI, which to a more significant extent have smaller classes and the attendant individual attention than what an "overcrowded" public university could provide. Thus students are increasingly being attracted to these PHEIs.

Parents also showed a high (86\%) awareness of performance indicators. Higher education studies for their children are more about academic success than issues of what a student will experience in terms of university life, sport, or cultural events on campus.

Sponsors show a low (30\%) response rate to performance indicators of a PHEI as their interest is more in their prodigies' success than the institution success. As indicated above, they have left the choice of institution to the individual student.

Corporate HR practitioners showed a low (42\%) response rate to the performance indicators of a PHEI, indicating that the graduate placement of a student is based on the NQF level obtained and not the performance indicator of the study institution. 
Students indicated a moderately high (76\%) response rate to the attributes or benefits of a PHEI. This would provide smaller classes and additional academic support as attributes and would not have benefits such as superior sports facilities, campus accommodation, or cultural activities. However, albeit with limited campus life attributes, students will still expect PHEIs to demonstrate or advertise their details that provide a solid and positive identity to the higher education institution they are studying at.

Parents (45\%), sponsors (30\%) and corporate HR practitioners (38\%) all show low response rates to attributes of PHEIs as their interest lies in academic success, which they regard as the most important. Students showed a moderate (54\%) response rate to the sustainability of the PHEI. Even though PHEIs in South Africa are in a growth stage, many of the larger PHEIs (from a student enrolment perspective) have been in existence for more than twenty years, indicating some level of sustainability and longevity of the higher education institutions.

The parent's response rate of $88 \%$ (high) indicates more awareness of the so-called "fly by night" institutions, and from a financial perspective, the parents would need to know the brand equity of the PHEI. Their interest would lie in the acquisitions of PHEIs by large corporates (local and international) who have moved into the field of higher education, for example, the emergence of PHEIs owned by significant corporates such as Adcorp, ADvTECH, Educor and Pearson Ltd. Sponsors (30\%) and corporate HR practitioners $(38 \%)$ shows low response rates to the sustainability of PHEIs as, once again, their interest lies in student success in achieving their qualification.

\section{PHEIs in emerging markets}

Ghauri and Cateora provided shared or common traits concerning the development and growth of PHEIs in emerging economies (Ghauri \& Cateora, 2010). In the South African context, these traits have been met by private higher education, as indicated in the discussion above. These factors include:

1. Providing potential for significant growth;

2. Undertaking programmes of significant reform, specifically concerning qualification diversity and accreditation; 
3. Growth of PHEIs have assured these institutions have become regional drivers, indicative of the national footprint of PHEIs throughout South Africa; and

4. Desire for further expansion into neighbouring markets (Southern Africa) as the South African PHEIs grow and develop.

South Africa as an emerging market meets all of the above factors whilst firmly establishing itself as one of the top ten big emerging markets (BEM) worldwide. At the same time, these factors are consistent with the phenomenal growth of private higher education providers in South Africa.

According to Nair, sustaining brands in emerging markets is in every bit as intricate and complex as it is in developed countries (Nair, 2010). One of the areas in the emerging markets that require additional knowledge and input is the traditional communication channel(s) that marketers utilise to advertise and promote their brands, which, based on accessibility from the marketplace, should be innovative and needs-oriented. Nair indicates that both developed markets and emerging markets currently use technology to create the ability of increasingly deep consumer engagement at each phase of the decision-making spectrum (Nair, 2010). This spectrum is identified as four critical areas, which are essential when a student or parent chooses to study at a private education institution. These four crucial areas are presented below:

1. When a consumer first decides to utilise a service and considers a few brands;

2. Active evaluation, when a consumer researches a potential service;

3. When the consumer selects a brand at the moment of brand selection; and

4. When the consumer experiences service selected - post decision.

Thus, the sustainability of a PHEI in South Africa, an emerging market, needs to be seen in the light of the above four factors when students choose whether to study at any one of these higher education institutions. Brazil, Russia, India, China and South Africa (BRICS), an international trading bloc of emerging market economies, is based on three categories of thrifts, namely (Cant \& Van Heerden, 2014):

1. Innovation-driven economies - developed or highly competitive countries with advanced economies and excellent infrastructure. 
2. Efficiency-driven economies - low to medium income countries, including BRICS countries; and

3. Factor-driven economies - low-income countries such as Iran, Egypt, Angola and Pakistan - developing countries.

Thus, it is evident from the classification above that South Africa, as an emerging economy, competes with fast-developing countries and finds itself part of both southern Africa and Africa, consisting of more factor-driven economies with untold health housing and other socioeconomic problems. Hence, the emerging-market concept is a factor to sustain an institution, specifically for the South African PHE sector.

Table 2 below provides a comparison of both developed countries and emerging market economies concerning infrastructure, lifestyle goods (television sets and cell phones), and essential services (water and electricity).

Table 2. Infrastructure of selected countries (developed \& emerging markets)

\begin{tabular}{lccccccc}
\hline Country & $\begin{array}{c}\text { Roads } \\
(\text { per } \\
1000 \\
\text { people })\end{array}$ & $\begin{array}{c}\text { Vehicles } \\
(\text { per } \\
1000 \\
\text { people) }\end{array}$ & $\begin{array}{c}\text { Electrical } \\
\text { power } \\
(\text { KWH) }\end{array}$ & $\begin{array}{c}\text { Mobile } \\
\text { phones } \\
\text { (per } \\
1000 \\
\text { people) }\end{array}$ & $\begin{array}{c}\text { PC's } \\
(\text { per } \\
1000 \\
\text { people) }\end{array}$ & $\begin{array}{c}\text { Colour } \\
\text { TV } \\
\text { (per } \\
100 \\
\text { houses) }\end{array}$ & $\begin{array}{c}\text { Shower } \\
\text { households) }\end{array}$ \\
\hline USA & 6304 & 859 & 12183 & 723 & 731 & 99 & 99 \\
\hline Brazil & 1724 & 79 & 1776 & 464 & 167 & 86 & 75 \\
\hline China & 1765 & 223 & 987 & 734 & 255 & 65 & 63 \\
\hline Germany & 6104 & 729 & 6046 & 785 & 625 & 92 & 97 \\
\hline India & 3315 & 120 & 380 & 146 & 185 & 42 & 41 \\
\hline Kenya & 64 & 110 & 120 & 112 & 55 & 46 & 43 \\
\hline $\begin{array}{l}\text { South } \\
\text { Africa }\end{array}$ & 476 & 143 & 3860 & 909 & 255 & 56 & 71 \\
\hline
\end{tabular}

(Adapted from Ghaum, updated 2018 (Ghaum, 2010)

Table 2 above illustrates the differences in both economy and infrastructure for both developed countries and emerging markets worldwide. The noticeable differences are prevalent in transport and technology, and media access. The importance of the disparity in cell phones per 1000 users versus access to a computer (255 users per 1000 in South Africa) showed, for this article, an impact on the ability to sustain a private education organisation amid basic needs and necessities as well as technology needs, necessary for a PHEI to function. Thus, this comparative table indicates that a sophisticated marketing programme that includes branding for specific markets still requires meaningful contribution from the organisation to reach the 
consumer and ensure economic success and growth, which are vital for PHEIs in emerging markets.

\section{South African PHEIs in International context}

In discussing the current state of PHEIs in South Africa, a comparison with international private education institutions will provide a window to benchmark, albeit in a limited way, the progress made by these PHEIs. One such comparison from an emerging economy, Brazil and Asia, was included in this study.

From 1996 the Ministry of Education in Brazil relaxed regulations on colleges offering private tuition throughout the country. Before this period, higher education could only be provided by public universities and non-profit organisations such as religious institutions (MacGregor, 2016). As a result of this deregulation, private colleges and universities have escalated significantly in the growth of their facilities and number of students. This growth period has seen mergers and take-overs occurring, with distance learning in Brazil becoming predominantly private and attracting over 120000 students, whilst showing bottom-line earnings over the US 1,5 billion dollars (MacGregor, 2016).

According to Goodson, Brazil has experienced phenomenal growth in the private education sector (Goodson, 2015). A comparative analysis between South Africa and Brazil's PHEIs would draw many similarities attributed to commonality in emerging economies. Much like the South African private education landscape, these similarities relate to the phenomenal growth that PHEIs experienced in both countries yet are also similar in the challenges they faced. For example, a lack of infrastructure investment and a lack of well-equipped laboratories and facilities are identical challenges. Magadza documented these challenges, stating that none of the Brazilian private higher institutions has research facilities, much like the South African private higher education sector (Magadza, 2013). This dramatic growth in the private providers in Brazil is also underscored by McCowan, who discussed the World Bank involvement in Brazil private higher education, promoting this expansion based on the private provider's ability to ensure a rapid increase in enrolments (performance) (McCowan, 2019). This growth of private higher education in Brazil has implications for their sustainability and the quality of their offerings. 
This upsurge in private education in Brazil has also attracted strong criticism from the traditional public institutions, citing factors such as:

1. Lack of well-equipped laboratories and facilities;

2. Lecturers not well paid and lacking skills and qualifications;

3. Little investment in infrastructure;

4. Minimal research conducted; and

5. Quality of the qualification deemed inferior.

These factors remain generic to most PHEIs worldwide. They are undoubtedly applicable to the South African environment, specifically from the measurement of quality of education, from both the higher education's institution's point of view and industry standards.

Other than the rise and growth of PHEIs in Brazil over the last decade, an important aspect emerged from research studies of PHEIs in Brazil. This merger between government and industry sparked interest by the Brazilian government concerning the importance of technology offered by private institutions in the formulation of the Brazilian General Command of Aerospace Technology (CTA). The advantage of government interest in a private education institution is twofold, namely:

1. It provides both financial resources, as well as support to the technological environment - an aspect that is essential for both the education and economy of a developing country; and

2. This government support sets the private institution up for graduate opportunities, as the partnership lends itself to aspirant graduates working in both the aviation industry, which is predominantly government driven in Brazil, as well as the technology industry - the growth industry.

This aspect was of interest to this study, as government partnerships with private education institutions could be an efficient and effective strategy to overcome challenges such as a lack of technical skills and a shortage of qualified teachers. This would assist the PHEI financially (sustainability) and employ trained teachers who work after graduating from government schools- in terms of having well-recognised and sustainable PHEIs that have government backing to address the critical skill-shortage of qualified professional teachers in South Africa. 
Another emerging factor from most developing countries in Asia showed that legislation that allows the privatisation of higher education institutions only came into being in the late 1990s (Chealy, 2006). This allowed two aspects to develop; firstly, the introduction of tuition and fees and, secondly, allowing special and executive programs to be offered Asian Development Bank (ADB) (Asian Development Bank, 2012).

Various factors that allowed for the privatisation of higher education institutions came into play. Most importantly, the increase in high school graduates across Asia led to a greater demand for more space in higher education. In addition, most Asian governments relied on the fact that, like most countries, both developed and developing nations that offer private higher education, typically receive little or no state funding - thus, like the South African personal education landscape, the PHEIs in Asia need to be self-sufficient (Asian Development Bank, 2012). Conversely, the Asian private higher education landscape with minimum or no state funding and, as a result, in contrast to South Africa, experienced minimal growth over the last two decades.

The legislation was also relaxed, which did not lead to a turnaround in the growth of private education institutions. In contrast, this caused more of a "spotlight" effect with these institutions coming under government scrutiny (Asian Development Bank, 2012). The article further postulates that a lack of funding from the government and low student enrollment led to a lack of demand for private higher education in most parts of Asia. At the same time, a lack of ability from private academic institutions to balance the marketing role (branding) and quality educational service delivery also contributed to this lack of demand.

Asian PHEIs provide helpful insight into most of their developing countries' similarities to the South African private education environment. Despite the growing number of high school graduates who look to higher education institutions in Asia, a lack of government funding of private institutions leads to lesser demand for private education in Asia than in South Africa.

In terms of their current status, funding, qualification accreditation, and branding of their private education colleges, Brazil and Asia were much aligned with the South African personal education landscape. 


\section{Strengths and weaknesses of PHEIs in South Africa}

PHEIs in South Africa and most countries where they are selffunded need to provide a setting where students, lecturers, and administrators believe their learning environment is an advantage in terms of student learnings (Mendenhall, 2016). This concept needs to be regarded as a strength for private education institutions. These South Africa private institutions offer a little lecture room for a small, relationship-building environment with most class sizes under 50 students. PHEIs have created lecture room spaces that enhance and complement their commitment to student engagement and success. An example of the learning environment created is the Independent Institute of Education (IIE) which is a private higher education institution operating across 21 campuses offering more than 90 registered and accredited programmes from Higher Certificate to Masters levels on its Varsity College, Vega and Rosebank college campuses Furthermore, the IIE commits to student success which includes a focus on innovative and supportive teaching methodologies, a comprehensive and holistic developmental student support system and the provision of learning opportunities that meets the diverse needs of the student population (Independent Institute of Education, 2020).

The limited class size and small learning environments are strengths for most PHEIs allow them to develop an array of structures and opportunities to bring community members together to connect. The university is an ideal higher education environment.

This learning environment strength is highlighted in one PHEI, which, although it encompasses 1900 acres, was designed to feel "small". The campus is organised in quadrangles that enclose and are separated by green spaces. Buildings are set back from the street, creating the sense that they are apart from the busy campus traffic noise. The feeling of smallness and a measure of intimacy for students in their learning environment is also attributed to Georgian style architecture for almost all the university buildings, with not one building taller than three stories. Thus, the campus is not a group of buildings near one another but have created a psychological mindset that "we are not as big as we are" and creates an intimacy of connections conducive to the thriving learning environment (Mendenhall, 2016).

Teaching and Learning methodology in the lecture room in private institutions, as part of classroom didactics, is another strength of the private education institution. Focusing on a smaller classroom 
environment, a learning environment can be implemented, focusing on a limited number of student numbers and thus more participation (Christensen \& Eyring, 2011). A scholarship program proves to be highly innovative to promote successful teaching and learning classroom didactics environment. Professor Jonathan Jansen, currently Head of the Faculty of Education at Stellenbosch University, previous Stanford graduate as well as a non-executive director of the IIE, proposes that scholarship is a fundamental purpose of higher education, more likely to be developed at the more demanding intellectual levels of analysis, synthesis, and evaluation specific to a smaller class environment (Anwar \& Noh, 2021). Scholarship, applied in most PHEIs in South Africa, suggests a scaffolding of learning so that students develop increasingly subtle and complex abilities. The most basic level describes copying a physical process, often with a great degree of active consciousness (imitation)- usually the group of new higher education students. After that, by the end of a degree programme, the expectation is that students should be able to engage in skilled, confident behaviour (for example, the use of a complex piece of equipment) without any need for conscious thought. The argument raised is that this scholarship programme will develop skills amongst students such as academic writing, gathering and analysing data and most importantly, an attitude and expectation of independent enquiry- all skills that will invariably contribute to a students' success in the private higher education environment.

Traditional higher education bases student learning on how many hours are spent in the classroom (reinforced by mandatory, stipulated hours of teaching necessary) and not necessarily how much a student has learned. Mendenhall, in a paper titled: "Game changers", discusses a new model for Higher Education, called Competency-Based Education (CBE) (Mendenhall, 2016). This concept was motivated explicitly for the struggling student who cannot keep up with the rest of the class and may need more time to learn and master specific concepts. Moreover, the variability of each course within the same degree programme at the same educational institution will mean that two students from the same program will not have equal levels of knowledge or competence. Thus, this programme, implemented at many private institutions, is based on students' confidence and by demonstrating mastery of competencies instead of earning credit hours. This programme provides learning communities for limited class sizes, wherein students can interact with course mentors and peers to discuss content and post questions. 
Table 3 below, shows an extension of Mendenhall's CBE model that drives student success at private institutions.

Table 3. Educator responsibilities at PHEIs

\begin{tabular}{ll}
\hline Traditional Institutional Role & \multicolumn{1}{c}{ Alternative approach at PHEI } \\
\hline Delivery of Instruction & $\begin{array}{l}\text { Technology delivers instruction } \\
\text { (Transformational digital learning } \\
\text { design) }\end{array}$ \\
\hline Course design & $3^{\text {rd }}$ part curriculum designers \\
\hline Selecting learning materials & $\begin{array}{l}\text { Faculty search to select best online } \\
\text { learning resources for teaching } \\
\text { didactics and assessments }\end{array}$ \\
\hline Assessment design & $\begin{array}{l}\text { Competencies determined and } \\
\text { assessments to measure each } \\
\text { competency (C-B L) }\end{array}$ \\
\hline Content support & $\begin{array}{l}\text { Subject-specific mentors available for } \\
\text { one-on-one and one-to - group } \\
\text { sessions reviewing content }\end{array}$ \\
\hline Mentoring & $\begin{array}{l}\text { Student mentors communicate } \\
\text { regularly with students not counsel, } \\
\text { advise, coach, organize and motivate } \\
\text { remotely or face-to-face. }\end{array}$ \\
\hline Grading & $\begin{array}{l}\text { Facilitators trained to grade based } \\
\text { upon a specific competency-based } \\
\text { rubric. }\end{array}$ \\
\hline
\end{tabular}

(Source: adapted from Mendenhall: Game changers)

Problem-based learning (or PBL) or Inquiry-based learning provides further argument and points towards the strength of PHEIs. The Lecturers can implement these learning designs in a small lecture room environment. In PBL, students go through an extended inquiry process in response to a complex question, problem or challenge. While allowing for some degree of student input, projects are carefully planned, managed, and assessed to help students learn key academic content, practise 21st Century skills such as collaboration, communication and critical thinking) and then create high-quality, authentic products and presentations. Thus, IBL gets students engaging with content through a driving question and inquiry to evidence their learning via presentations (small group environment) to the group and Lecturer.

Anne Waits, National Academic Manager at a large PHEI in South Africa, presented a paper on Transformative Digital Learning design at a PHEI conference in 2016 that provided a new culture of learning. This opened a unique learning environment and gave 
another strength of PHEIs relative to digital learning design. Arguably, the modern-day classroom must be equipped for the digital age for the 21 st Century school leaver and student to relate to. Thus, in private higher education, technology in the classroom acts as an agent for transformational change in learning design. IBL justifies one such learning design as it applies the components of learning design in learning tasks (projects), learning supports (frameworks and inductivism) and learning resources (web links, case studies, internet). These technology-driven learning designs provide an opportunity for students to build and evidence their skills of critical thinking, communication, collaboration, and creativity.

PHEIs focus on building student careers in a small, controlled learning environment. There is an understanding that students undertake tertiary studies as the first step in their careers and that what they learn and how they learn need to lay the foundation for further growth, employment, and learning. The majority of PHEIs in South Africa have curricula relevant to the modern world of work. They build strong industry and academic partnerships that ensure and assure this relevance.

\section{Challenges facing PHEIs}

Christensen \& Eyring wrote in their book: 'The Innovative University" that for the first time, disruptive technologies are at work in higher education (Christensen \& Eyring, 2011). For most of their histories, some carrying over 150 years, traditional universities and colleges have had no severe competition except other universities with similar operating models. Now, disruptive competitors are offering face-to-face tuition and online courses. Many of these institutions operate as for-profit entities, emphasising marketable degrees for school levers and working adults. Traditional colleges and universities have valuable qualities and capacities that can offset those disruptors' advantages - but not for everyone who aspires to higher education without real innovation. The bottom line is that private colleges in higher education cannot be seen as a real competitor to a private university- that is ultimately the challenge facing PHEIs. Christensen $\&$ Eyring further discuss three factors that resolved the anomaly of traditional universities in so-called decline. Firstly, teaching was challenging to disrupt as its human qualities could not be replicated. However, the argument posed that one of the strengths of a PHEI lies in technology with a transformative digital learning design does not hold with this point. A digital learning design utilised by most PHEIs does not do away with the human element - it complements it. 
Secondly, observation and perceptions indicate that the campus experience is central to a student's university experience. One must concede that this would be very difficult to emulate from a private education perspective and is considered a significant challenge for any private institution (Christensen \& Eyring, 2011).

Large campuses with sports fields, auditoriums, halls, theatres are not part of the learning landscape for many PHEIs. Arguably, the strength of private institutions is confined to small, intimate campuses, yet it does not provide the campus life of a large sprawling traditional university. And the third reason why higher education has seen many new entrants not only in South Africa but worldwide is alumni and state financial backing, the downfall of private education. Alumni and state support gives traditional universities and colleges staying power unique to higher education.

The traditionalism of some public universities dates back over 150 years, which has allowed these institutions to build a mantra that carries forth from generation to generation, and parents to their children. The fledgling state of private higher education does not allow for this traditionalism. This becomes a challenge in recruiting the wealth of new entrants and school leavers wanting to study at a university.

Fry, Kettridge \& Marshall discuss the "New Learning Revolution" that maintains that the general goal in a higher education landscape is to move up, grow, and develop, notwithstanding the high cost of doing so (Fry, Ketteridge, \& Marshall, 2012). They cite the example of Harvard University Business School, stating the difficulty of simultaneously raising the school's quality, decreasing its costs, and serving more students. Among other things, this meant becoming more selective in admissions (looking at students'/ parents' financials before access!), bolstering the faculty's research and publication quality and quantity to enhance the program's reputation in the eyes of other academic leaders- crucial initiatives and expensive ones requiring fueling and input from federal(state) research grants and student subsidies per registration.

Another challenge for PHEIs in South Africa pertains to the need for faculty's research and learning facilities to be continuously upgraded and developed to maintain accreditation of their qualifications. This is indeed a significant challenge for PHEIs because they are self-funding and do not receive state grants or subsidies. The lack of research facilities at most PHEIs in South Africa is indicative of the status they have as universities. By law, PHEIs in South Africa may 
not call themselves private universities (Council on Higher Education, 2020). However, private institutions are subject to the same regulations, accreditation requirements and oversights as public universities. South Africa's single quality assurance and one National Qualifications Framework (NQF) means that any institution offering a registered and accredited qualification- whether public or private- is offering a capability of equal standing.

In summary, many private colleges do not perform all of the functions that universities do, scholarly research and the granting of $\mathrm{PhD}$ degrees being leading examples. However, the things that private colleges (especially the larger ones) do, mainly the methodology used to educate students, have been determined primarily by universities. Because of these similarities, one will find that many of the threats and opportunities facing traditional higher education institutions are the same for both universities and private colleges in South Africa. The subtle difference will lie in the challenge of a private college being self-funding and thus self-sufficient- a delicate balancing act.

\section{PHEIs branding proposals}

The strengths of PHEIs in South Africa can, at face value, be negated by the challenges facing private colleges - funding being one of the major ones. As indicated previously, most of the PHEIs in South Africa have a corporate identity, and all the larger ones are part of a large conglomerate. This renders these private institutions profitdriven and has other stakeholders to account for and answer to students. The major strength described above is the classroom didactics delivery, and learning environments created that ensure student academic success. A PHEI needs to operate within a specific location to the campus and then advertise this strength and brand to the local community.

PHEIs need to differentiate themselves and create a sustainable competitive advantage for their businesses. The findings and analysis in Table 1 above indicate that, initially, PHEIs were not that wellknown amongst significant stakeholders. Thus, with the resultant allocation of resources for management to brand and advertising, the development of a value-added branding framework can collectively enhance the brand awareness of PHEIs and build relationships with stakeholders to change public perception of the brand image of private higher education in South Africa. Even though no clear distinction emerged in this area, it was evident that different stakeholders respond differently to specific branding and subsequent brand advertising. 
Thus, of relevance to the PHEI brand is a differentiated consumer behaviour approach that combines marketing communications of a social media nature for students and more traditional advertising for parents. The Independent Institute of Education (IIE), a benchmark for PHEIs, seems to have the mix right since it has an interactive website that relates to students and an awe-inspiring television advertisement that focuses on student success relevant to parents' expectations. In addition, their social media reach to students has facilitated many students making enquiries about studying at their various campuses.

Another aspect that emerged from Table 1 was the minimum communication channels between the PHEI and corporates. The distinct lack of communication between the PHEI and corporate HR practitioners culminated in poor relationship building between these two parties. This lack of communication with corporate HR practitioners topped in poor graduate placements of students from PHEIs. PHEIs need to establish a clear line of communication with corporates.

In addition, Table 1 highlights the third avenue of input related to the sponsors, both corporate donors and individual financial contributors, who, whilst not prime decision-makers in the choice of the PHEI, were not acutely aware of the PHEI brand. Whilst, as sponsors, they would abide by their protégés as to which education institution they wanted to attend, they would always be concerned with the brand performance of the PHEI and how well-known the brand is was.

A case in point with relevance to the issue raised in the opening paragraph regarding the public's lack of knowledge of PHEIs, provided the fourth avenue about Table 1, which was the branding of the academic governing body/ holding company of a PHEI. Two examples would be the IIE in the case of Varsity College (varsity college, 2019) and Pearson Ltd for CTI College (now renamed Pearson College for Higher Education) (CTI, 2019), which are both listed and represented on the Johannesburg Stock Exchange but have little brand recognition amongst the general public. A clear line of synergy should be drawn between promoting the academic governing body and the individual brand, bearing in mind that the students spend most of their time relating to the latter on the brand's campus. Knowledge of a brand with a proven track record of success and sustainable brand equity will attract more students to a specific PHEI. 
The implications for the policy was determined by the Higher Education Act 1997, which governed the establishment of PHEIs in South Africa and brought control and legislation to the development of PHEIs. Implications for a theory of this study related to the works of both Keller and Aaker's who determined benchmarks and frameworks for the branding of both a service much like a PHEI (Keller, 2013);(Aaker \& Joachimsthaler, 2009).

\section{Conclusion}

There is a perception problem (both from the media and public) that PHEIs in South Africa face from all community sectors. When students, parents, sponsors and corporate HR practitioners ask the inevitable question from more than ninety private education institutions as to: "Who is your organisation?" and: "Is your institution accredited?" the stakeholders should distinguish little difference between a private and public higher education institution.

This will require innovative thinking and resources (finance) made available from PHEIs and will require marketers and PHEI management to "think out of the box" concerning unique and creative ways to brand their institutions, providing a competitive advantage respective PHEIs.

Should this occur, PHEIs in South Africa will no longer have to scrutinise their qualifications in terms of them being locally or internationally accredited. PHEIs, although not having the tenure or traditionalism of a public university, will be able to advertise academic success, more substantial support, innovative and technologicallyenhanced classroom and lecture didactics, professionalism, and relationship building with stakeholders owing to their smaller and more controlled environments. They need to know thoroughly how to reach these stakeholders to advertise these drivers of PHEIs.

The South African education landscape needs the footprint of Private Higher Education Institutions (PHEIs). This will be of mutual benefit to the government and public and private education. 


\section{Bibliography}

Aaker, D. A., \& Joachimsthaler, E. (2009). Brand Leadership. London: Simon and Schuster.

Anwar, S., \& Noh, M. A. C. (2022). Evaluasi Pendidikan Menuju Insan Kamil Perspektif Filsafat Islam. JURNAL PENDIDIKAN NUSANTARA, 1(1), 62-76.

Asian Development Bank. (2012). Private Higher Education across Asia: Expanding Access.

Badenhorst, A. J. (2019). This is how South Africa can handle the growing demand for Higher Education.

Cant, M. C., \& Van Heerden, C. H. (2014). Marketing Management: A South African Perspective. Cape Town: Juta.

Chealy, C. (2006). In Higher Education in South- East Asia. Bangkok: UNESCO, APEID.

Christensen, S., \& Eyring, H. (2011). The innovative university - changing the DNA of Higher Education from the inside out. San Francisco: Wiley \& sons.

Council on Higher Education. (2020). Register of Private Higher Education Institutions.

CTI. (2019). Prospectus In Untiled.

Fehnel, R. A. (2006). Transformation in Higher Education. Amsterdam: Springer Publishers.

Froneman, L. (2012). Private Higher Education Institutions in a changing South African Environment. Act Commercial 2009, 2(1), $35-36,38$.

Fry, H., Ketteridge, S., \& Marshall, S. (2012). A handbook for Teaching and Learning in Higher Education. London: Routledge.

Ghaum, S. (2010). The making of Kabhi Khushi. New Delhi: Routledge.

Ghauri, P. N., \& Cateora, P. (2010). International Marketing. Berkshire: McGraw- Hill.

Goodson, S. (2015). Why brand building is important.

Ikhwan, A. (2021). Metode Penelitian Dasar (Mengenal Model Penelitian dan Sistematikanya). Tulungagung: STAI Muhammadiyah Tulungagung.

Independent Institute of Education. (2020). Private Higher Education 
Institution.

Keller, K. L. (2013). Strategic Brand Management: Building, measuring, and managing brand equity. New Jersey: Pearson Education.

Mabelebele, J. (2015). HE in South Africa: emerging challenges and implications for universities. University of Limpopo.

MacGregor, K. (2008). South Africa: Private higher education stabilises.

MacGregor, K. (2016). Brazil: Private education far better than none at all.

Magadza, M. (2013). Wake up call for the higher Education sector.

McCowan, T. (2019). The growth of private higher education in Brazil- implications for equity and quality.

Mendenhall, R. (2016). Game Changers. Cape Town: Paper presented at $\mathrm{HE}$ conference.

Mufron, A., Ikhwan, A., Syuhada, M., \& Ridlowi, A. (2021). Optimizing the Organizational Structure in Transforming Human Resources Who Can Manage Work Stress With a Religious Culture. European Journal of Molecular $\&$ Clinical Medicine, 8(3), 1110-1126.

Nair, E. T. (2010). Emerging markets: The future. Harvard Business Review, 21.

Olonisakin, F. (2013). Lessons and challenges for education in Africa.

Ramdass, K., \& Kruger, D. (2010). The challenges facing Higher Education in South Africa. Higher education conference: Paper presented at University of Johannesburg.

Syarifudin, A., \& Ikhwan, A. (2020). Determinant Factor of Personality Changes in Education. Journal of Critical Reviews, 7(Innovare Academics Sciences Pvt. Ltd), 518-524. 